Check for updates

The BMJ

Cite this as: BMJ2020;371:m4968 http://dx.doi.org/10.1136/bmj.m4968 Published: 30 December 2020

\section{Covid-19: UK approves Oxford vaccine as cases of new variant surge}

\section{Elisabeth Mahase}

The UK's medicines regulator has approved the Oxford and AstraZeneca covid-19 vaccine, which will be administered as two standard doses-the second within 12 weeks of the first.

The Joint Committee on Vaccination and Immunisation has said that vaccinating as many at risk people with the first dose as possible will now be the priority, as opposed to the previous strategy of giving people two doses within a few weeks. Vaccination with the new vaccine will begin on 4 January, said the health secretary for England, Matt Hancock. With the Pfizer-BioNTech vaccine, the UK now has enough doses to vaccinate all adults with two doses.

The approval of the new vaccine comes as most areas in the UK were moved up into higher tiers of restriction to try to stem the spread of the virus. More than 53 ooo new covid-19 cases were reported across the UK on 29 December, most of them the variant called B117.

The UK has ordered 100 million doses of the Oxford vaccine, the first batch of which was released late on 29 December following the approval.

The Medicines and Healthcare Products Regulatory Agency announced the approval on 30 December, concluding that the vaccine was safe and effective for those most at risk of death and serious illness from covid-19.

Published efficacy data from the Oxford vaccine trial show that the vaccine was $62.1 \%$ effective in participants who received two standard doses $(\mathrm{n}=4440)$ and $90 \%$ effective in those who received a low dose followed by a standard dose $(n=1120){ }^{1}$

Speaking at a televised press briefing, Wei Shen Lim, chair of the Joint Committee on Vaccination and Immunisation, said that data shared with the committee-which have not yet been made publicly available-calculated the vaccine efficacy in the period between day 22 after the first dose to the time of the second dose was around $70 \%$.

Both the Pfizer and Oxford vaccines are now being rolled out to the priority groups including care home residents and staff, people over 80 , and health and care workers. However, the Oxford vaccine can be stored at fridge temperatures $\left(2-8^{\circ} \mathrm{C}\right)$, making it easier to distribute to care homes and other locations across the UK than the Pfizer vaccine, which requires dry ice storage and only lasts five days in a fridge.

Helen Fletcher, professor of immunology at the London School of Hygiene and Tropical Medicine, said, "Approval of this vaccine is a turning point for the pandemic because it has been deliberately developed to have global impact that includes people living in the most fragile and poorest regions of the world. With more than 30 supply agreements and partner networks established globally the Oxford-AstraZeneca vaccine could slow the pandemic and should save many lives within the next year."

Others have emphasised that, although this is a step in the right direction, the infection rate still needs to be brought down while the vaccine is rolled out.

Deenan Pillay, professor of virology at University College London and a member of Independent SAGE, said that even with another vaccine becoming available it was more important than ever to limit the spread of infections because the virus has proved more prone to mutations and variation than many people had thought.

"One big concern is that we will see continuing evolution of this virus - more and more variants that build on the one that is highly transmissible-and that will happen with ongoing transmission and replication. Without replications and transmission there is no evolution of the virus. In order to maximise the effectiveness of the vaccines coming through we really need to lockdown and reduce all chances of transmission," he said.

\section{Pfizer vaccine}

Alongside the Oxford vaccine approval, the Medicines and Healthcare Products Regulatory Agency announced changes to who and when people can get the Pfizer vaccine. Pregnant and breastfeeding women can now receive the vaccine, as can people with allergies-unless they are allergic to the vaccine ingredients. People should also get their second dose of the Pfizer vaccine at least 21 days after the first dose, rather than at 21 days.

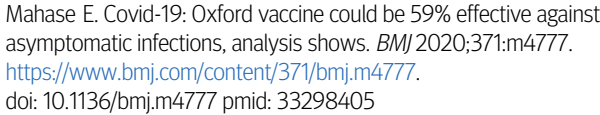

This article is made freely available for use in accordance with BMJ's website terms and conditions for the duration of the covid-19 pandemic or until otherwise determined by BM]. You may use, download and print the article for any lawful, non-commercial purpose (including text and data mining) provided that all copyright notices and trade marks are retained. 